\title{
The Brazilian Psychology Postgraduate System and the Internationalization Process: Critical Aspects, Evaluation Indicators and Challenges for Consolidation
}

\author{
A Pós-Graduação em Psicologia no Brasil e o Processo de Internacionalização: \\ Aspectos Críticos, Indicadores de Avaliação e Desafios para Consolidação.
}

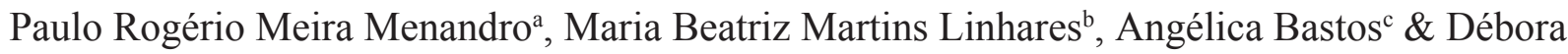 \\ Dalbosco Dell'Aglio ${ }^{\mathrm{d}}$ \\ ${ }^{a}$ Universidade Federal do Espírito Santo, Vitória, ES, Brazil, ${ }^{b}$ Universidade de São Paulo, Ribeirão Preto, SP,

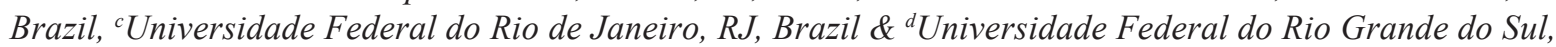 \\ Porto Alegre, RS, Brazil
}

\begin{abstract}
The paper discusses aspects of internationalization policies pertaining to research and postgraduate training programs in Brazilian psychology. Indicators from eight areas of knowledge, used by CAPES (Coordination for the Improvement of Higher Education) to assess the level of internationalization of the postgraduate programs, are presented to support the arguments. The authors contend that: a) internationalization is not a theme limited to the strict framework of science and technology, requiring knowledge of cultural, educational, economic and political aspects; b) different axioms and rules apply to different areas of knowledge; c) collaboration with researchers from different centers can be more beneficial than focusing only on publishing in foreign periodicals; d) coordination and collaboration between researchers does not require alignment of national research agenda to the standards of foreign research centers. Indeed, internationalization is recognized and is rapidly developing in academic institutions and support agencies. In this process, challenges are presented to postgraduate programs: a) to ensure that communication extrapolates the limit of the Portuguese language and is in the language appropriate to the context of the student/researcher; b) to reduce bureaucratic obstacles that hinder cooperation in Brazilian universities; c) to support arrangements and policies that facilitate joint funding proposals with other countries that benefit Brazilian science and technology. Keywords: research in psychology, postgraduate system, internationalization, scientific cooperation
\end{abstract}

\section{Resumo}

O texto discute aspectos em políticas de internacionalização da pesquisa e da formação pós-graduada no atual contexto da Psicologia no Brasil. Indicadores de oito áreas de conhecimento para aferir o nível de internacionalização dos programas de pós-graduação, utilizados no processo avaliativo conduzido pela Capes, são apresentados para embasar esta análise. Os autores argumentam que: a) internacionalização não é tema limitado ao âmbito estrito da ciência e da tecnologia, exigindo considerar aspectos culturais, educacionais, econômicos e políticos; $b$ ) diferentes axiomas e regras são aplicáveis a diferentes áreas do conhecimento; c) colaboração com pesquisadores de diferentes centros pode ser mais eficiente do que privilegiar apenas submissão pontual de textos a periódicos estrangeiros; d) articulação e colaboração entre pesquisadores não obriga o alinhamento de agendas de pesquisa nacionais ao que é privilegiado em centros de pesquisa no exterior. Com efeito, a internacionalização é reconhecida e está em franco desenvolvimento nas instituições acadêmicas e nas agências de fomento. Em tal processo, desafios se apresentam aos Programas de Pós-Graduação: a) assegurar que a comunicação extrapole o limite da língua portuguesa e se componha com o idioma local pertinente ao cenário internacional com o qual o estudante / pesquisador irá se relacionar; b) reduzir entraves burocráticos que dificultam a cooperação nas universidades brasileiras; c) contribuir para que agências de fomento à pesquisa estabeleçam acordos que resultem em editais conjuntos com outros países, assegurando condições de acesso a concorrências viáveis e garantidores de benefícios à ciência e à tecnologia brasileiras.

Palavras-chave: pesquisa em psicologia, sistema de pós-graduação, internacionalização, cooperação científica

Correspondence concerning this article should be addressed to Paulo Rogério

Meira Menandro; PPGP/UFES; Av. Fernando Ferrari, 514; Goiabeiras;

Vitória/ES CEP 29075-910. E-mail: paulomenandro@uol.com.br 
The aim of this text is to present and discuss aspects of the internationalization process of research and postgraduate qualification in Brazilian psychology. The text is organized into three parts. In the first, critical considerations are presented regarding the process of internationalization, the elements that determine it, its potential to increase scientific knowledge, and its limits and risks. In the second part, information is presented regarding how the evaluation process of the postgraduate system has relied on performance indicators in psychology and in seven other areas of knowledge. Challenges in the development of the internationalization process are presented and discussed in the final part of the text.

\section{Critical aspects of the internationalization of the Brazilian postgraduate system}

Addressing the theme of internationalization of the Brazilian postgraduate system permits discussion of several critical aspects, of which four are featured in the first part of this study: contextual implications that go beyond the sphere of science and technology, delimiting contingencies, potential for the expansion of scientific knowledge, and limitations and risks.

The first issue is that internationalization is not a theme situated within the strict framework of science and technology. Quite the contrary, internationalization requires the understanding of factors such as: cultural diffusion, educational standards, economic growth, government priorities, and political and diplomatic presence in the country. Furthermore, it is related in some cases, to what the country has to offer in terms of data for international research. In the case of Brazil, among other examples, seas, watersheds, forests, animals, plants, specific ecological niches, mineral reserves, energy sources, geological characteristics, agricultural and livestock production and innovation patterns, industrial production and innovation patterns, fossils, archaeological evidence, languages, migration, diseases, indigenous populations, dynamics of urban and rural populations, cultural manifestations, and political and social organization can be mentioned.

Internationalization also concerns the conviction that many Brazilian problems, potentials and achievements need to be comprehended within the international context, but also without neglecting the development of domestic studies and propositions, and without subordination or inferiority. Through this internationalization process, Brazilian scientific output can reach a global audience, including scientists from North America, the U.K., Germany and France.

At the current time, evidence is found of modest international interest in Brazilian psychology. The citation of Brazilian journals is limited. Brazilians who publish internationally in various sub-areas of psychology are aware of these constraints, even if their work appears in English in national journals. However, immersion in the international context (U.S., Canada and certain European countries) does not mean we have to disregard the production of Brazil. We occasionally find Brazilian texts examining an aspect of Brazilian life that have no references to studies from Brazil.

Clearly, the issue of access to Brazilian texts was hampered by the precariousness of the publications and by the absence of inclusion on indexing databases. This framework represented a barrier for the citation of such texts, however, in the last two decades technology has radically affected the availability of scientific texts. The quality of the publications mentioned has risen, and the role of indexing has greatly changed, which introduces new aspects in the discussion of the theme. It is naive not to consider, additionally, that the process of dealing with publishers requires citation strategies. Even if there are no direct explicit requirements, the editor is aware of the impact of citation rates and, consequently, the production of the country to which the publication is linked.

One possible recommendation that can be contemplated is the publication, in Brazilian journals, of Englishlanguage review texts. This practice could increase the visibility of studies due to the fact that they are presented in a more articulated, more contextualized way - a way that highlights developments, interpretations, applications and limitations. In this way, the interest of foreign researchers could increase in relation to works that are only available in Portuguese, requiring translation efforts in the opposite direction to the norm.

On the other hand, there has been a progressive increase in the indexing of Brazilian publications in international databases and a concomitant increase in Brazilian citations abroad (Packer, 2011). Psychology is situated in such a framework. We also know that there are more Brazilians studying, performing research, and working abroad; and more foreigners studying and performing research in Brazil. These facts may explain the increase in citations, especially in articles in Portuguese. Studies in cooperation with foreign researchers are fundamental for these advances. Furthermore, we know that citation in the human sciences involves a decision which considers theoretical, political, and methodological aspects; and even writing, with argumentative implications. In contrast, the implications mentioned are not as frequently observed in other areas in which internationalization is imperative. In these areas, the works are based on previous studies on the same subject using comparable equipment, data sources and methods, which always assures their citation. This subject is explored in more detail in Menandro, Yamamoto, Tourinho and Bastos (2011).

It is clear that the language barrier is involved in this theme. The large number of Portuguese native speakers comes from the ample size of the Brazilian population, to which the lesser population of Portugal is added, as well as members from the lower-producing former Portuguese colonies (Angola, Mozambique, Guinea-Bissau and 
Menandro, P. R. M., Linhares, M. B. M., Bastos, A., \& Dell'Aglio, D. D. (2015). The Brazilian Psychology Postgraduate System and the Internationalization Process: Critical Aspects, Evaluation Indicators and Challenges for Consolidation.

East Timor). This barrier is not presented with the same characteristics in all areas of study. In history, political science and literature, for example, there are centers of Brazilian studies in institutions in foreign countries, all dealing with material in Portuguese. The growth of the interaction and sharing of texts between Latin American researchers has also affected the issue of the language barrier. It is worth remembering that the realization of Latin American integration is a target stipulated in the Brazilian Constitution (Marrara, 2007).

It is also important to highlight the decreasingly remote possibility that the language barrier may become a negligible factor of expression in the coming years, at least in relation to published texts. The moment can not be too far off when a scientific paper published in one language can be instantly read in another language, due to careful automatic translation that will guarantee the transposition of the text into other languages. This possibility has important implications in many areas of knowledge, for programs and lines of research in which there is intense scientific cooperation with laboratories and universities of countries such as France and Belgium, for example. For these countries, English is not a language barrier, however, there are prestigious publication media in French, which are not always indexed or evaluated at the international level that encompasses most of the other publications. Similar points were highlighted in Lo Bianco, Almeida, Koller and Paiva (2010).

Nevertheless, the fact that very few Brazilian postgraduate programs offer courses in languages other than Portuguese has been a limiting factor for foreign students to be received in Brazil, as there is little motivation for foreign students to learn Portuguese - a secondary language in the scientific realm. However, this limitation does not apply to Latin American countries, the students of which, attracted by the Brazilian postgraduate system, enjoy the linguistic proximity between Portuguese and Spanish, as well as the support of the scholarships they are offered.

The second issue in the first part of the text concerns the inadequacy of applying the same rules to different areas of knowledge, or even sub-areas of knowledge. This understanding would allow full comparability between areas, leading to the conviction that the imposition of the same requirements and the adoption of the same measurement criterion to deal with them are justified. It is important to discuss the implications of the diversity of various areas in terms of: the nature of the research they include, the comparison of results that they require, the inevitable internationalization due to the fact that research relies on use of the same equipment anywhere, or the influencing factor of contextual diversity that affects the study theme. Lo Bianco (2009) warns of the danger of requiring international indices - homogeneous indices - in a heterogeneous universe.

In Astronomy, for example, the research community can allocate the use of a large telescope for a few hours a year to different groups, according to the interest of national projects. This allocation is an expression of internationalization, enabling assimilation between different research groups. There is nothing equivalent in the human sciences. Another example concerns the possibility that, in more egalitarian societies, with people of similar economic status and access to information, research using numerous procedures or instruments (interviews, narratives, evocations, scales, tests, response latency) would produce results with less variability, i.e., analyses with less distortion. While adaptations and validations reduce the risk of mistakes, they can bias what is being measured. In any case, we must remind ourselves that poverty is not the same in every poor country, despite similarities in economic frameworks. As religion is not the same in all religious countries; and racism not the same across all racist cultures.

The third question concerns the pragmatic and possibly limited view regarding the issue of international production. This view concerns the final stage of the academic process: the submission of English-language texts to certain journals. With English as the lingua franca, these texts have a higher likelihood of being appreciated by international researchers, who know little of the Brazilian reality. In some sub-areas the reviewer will not be able to identify the geographical setting of the research; however, in others, the context of the study is revealed within the text to clarify the scientific content. It may be more interesting, instead of concentrating efforts on this final translational stage, to consider the primacy of other actions; actions such as: the articulation and collaboration between researchers, which can be a more effective strategy due to the regularity, the ramifications, the ongoing character, and the heightened interest a joint publication creates among publishers and readers. This framework utilizes the different types of interaction-passive and active (Marrara, 2007).

A fourth point references the fact that talk of cooperation and collaboration between researchers does not necessitate alignment of national research lines to the needs and standards of international research centers, to secure publication in international journals. While this proposal is a frequent topic in scientific debates, we must consider whether this approach will benefit Brazilian psychology. The adjustment of themes, methodologies and theoretical foundations to those of international research centers may assure publication in international journals for a while; it may also dampen innovative contribution.

\section{Current criteria for Internationalization in different areas of knowledge according to the CAPES classification}

The Coordination for the Improvement of Higher Education Personnel (CAPES) is the government agency 
responsible for promoting and evaluating postgraduate programs. This work is handled by peer committees based on information provided every year on activities developed, and scientific and technical production performed. As part of their activities, these peer committees produce reports on the evaluation process for which they are responsible. These reports include information on the internationalization criteria that were applied for the assignment of grades 6 and 7 . These grades are at the top of a scale ranging from 2 to 5 , in which programs graded 2 are disaccredited, and programs graded 5 compete for the additional grades of 6 and 7. The additional grades are reserved for programs that, in addition to compliance with various performance requirements, exhibit internationalization indicators in their activities and productions.

The internationalization indicators of psychology and seven other areas were selected for presentation. Some of these areas were chosen because they are comparable with psychology, due to different configurations of thematic proximity. An area of medicine without such features was included as an additional comparative element. These indicators are: Medicine II (Infectious and Parasitic Diseases / Infectology, Pathology, Pediatrics / Child and Adolescent Health, Neurology / Neuroscience, Psychiatry / Mental Health, Radiology and Diagnostic Imaging, Hematology, Rheumatology, and Programs in the Health Sciences category), Medical III (General Surgery and all surgical specialties), Education, Interdisciplinary, Public Health, Sociology and Nursing.

The data source was the set of final reports of the evaluation of CAPES (2010-2012 triennial) prepared by the different areas. The following excerpts of the considerations and justifications of these reports are presented, using the criteria specification recorded there to compose a summary table which is presented at the end of the transcripts.

\section{Psychology}

This presentation begins with the record of the criteria considered by the psychology area for the assignment of grades 6 or 7 . The initial condition, which is the same for the various areas, is that the programs present performance that justifies the assignment of concept 5 , showing indicators of excellence in the first stage of the evaluation. Next, additional requirements were applied, distributed over four axes, namely: 1) level of internationalization of scientific production; 2) level of internationalization of academic and scientific interactions; 3) leadership of the program and its professors; 4) knowledge transfer to new postgraduate programs and performance of graduates.

CAPES evaluates internationalization from a comparative perspective. The organization bases $40 \%$ of its evaluation of internationalization on: a) percentage of production published in international journals qualified as $\mathrm{A} 1, \mathrm{~A} 2$ or B1; b) balance of the international production among the teaching body with higher qualifications; c) existence of productions in partnership with foreign researchers; d) existence of publications in well-qualified international journals authored or co-authored by a student; e) existence of books (full text or organization), or chapters of books published abroad; f) evidence of international impact of the productions (citations in foreign publications); g) evidence of international impact of technical productions; h) international awards for work published or presented at events. Compliance with the requirements of items $a$ and $b$ is necessary for the recommendation of an increase in grade. The comparative classification of the performance indicators in this axis defines the assignment of grade 6 or 7 for recommended programs.

Regarding internationalization of the academicscientific interactions (with a weighting of $30 \%$ of the total grade in the item), the indicators take into account: a) participation of professors on editorial committees and as editors of international journals; b) participation of professors as members of examination boards, teaching courses or as coordinators of postgraduate programs abroad; c) coordination, co-supervision and/or supervision of foreign students in Brazilian programs; d) coordination of foreign doctors in postdoctoral training; e) performance, by professor or graduate, of internship/training, technicalscientific and/or postdoctoral activities in foreign institutions; f) performance, by students, of internship/ training abroad, especially through scholarships-sandwich programs; g) participation in international committees and boards of associations, scientific societies and programs (of research and technical development); h) raising of resources from international scientific funding agencies; 1) participation of professors in international events (conferences, award committees, participation and coordination, or mediation in round tables and symposia); j) qualified participation (as a guest or presenter of work) of professors and/or students in scientific events abroad or in international itinerant events in Brazil; k) research projects in conjunction with foreign support or research centers; 1) receiving visitors or foreign guests for postgraduate research and/or teaching activities; $m$ ) participation in organizing international events abroad, or organization of international itinerant events in Brazil. Evaluations are conducted from a comparative perspective.

Regarding the leadership of the program and its professors (with a weighting of $15 \%$ of the total grade in the item), the indicators take into account: a) attracting students from different regions of Brazil and other countries; b) participation of the professors in advisory committees of international, national and state support agencies; c) awards received by professors, in Brazil or abroad, related to their research activities or research developed under their guidance; d) participation of professors on boards of scientific societies or postgraduate associations; e) participation of professors in positions relevant to the national or state policy on health, education, 
Menandro, P. R. M., Linhares, M. B. M., Bastos, A., \& Dell'Aglio, D. D. (2015). The Brazilian Psychology Postgraduate System and the Internationalization Process: Critical Aspects, Evaluation Indicators and Challenges for Consolidation.

social assistance, public administration or science and technology; f) number of professors with CNPq (National Council for Scientific and Technological Development national research funding agency) grants or scholarships from state agencies that show differential recognition of performance in the area; g) performance of professors as supervisors of postdoctoral training. Again, evaluations are conducted from a comparative perspective.

Regarding Knowledge Transfer of the Program and Practice of Graduates (with a weighting of $15 \%$ of the total grade in the item), the indicators, considered as a set, take into account: a) participation of professors in teaching activities and/or research cooperation in other institutions in Brazil or in countries with higher education institutions in a stage of consolidation; b) participation of professors in advisory activities (through indication by CAPES) in other institutions in order to contribute to creating projects or consolidating postgraduate programs; c) prominence of program graduates as professors in other, public and private, prestigious educational institutions; d) prominence of program graduates as supervisors in postgraduate programs in the area or related areas; e) prominence of program graduates in public institutions, in fields related to their program study; f) prominence of program graduates with CNPq Productivity Scholarships. Evaluations are conducted from a comparative perspective.

Medicine II (Infectious and Parasitology/Infectology, Pathology, Pediatrics/Child and Adolescent Health, Neurology/Neuroscience, Psychiatry/Mental Health, Radiology and Diagnostic Imaging, Hematology, Rheumatology, and programs in the Health Sciences category)

Internationalization can be measured by the prominence of professors and students in scientific activities abroad, by the offering of disciplines and courses of international scope, and by the prominence of foreign students in the programs, among others. These variables are related to upgraded scientific English in the Medicine II postgraduate programs.

For a long time, various aspects of internationalization have been used in evaluations and are basic objectives of the Medicine II programs. When comparing highly-ranked programs in Medicine II (grades 6 and 7) with international programs, one will note important differences. Foremost is the difference that in the majority of prominent foreign centers, medical research is primarily performed by researchers and post-doctorate candidates; while in Brazilian centers, it is grounded in the postgraduate system. However, the medical programs that receive grades of 6 or 7 have similar characteristics to the international centers, such as the insertion of intellectual production in divulgation media of international access, as well as the measurement of production by citation indices, the prominence of foreign students and professors in international research networks, or on the board of international scientific associations, or as members of editorial boards of internationally renowned journals.

The program performance is also evaluated with regards to the training of human resources, particularly doctors, and the knowledge transfer to research groups across the country, and the integration of students and graduates into research and postgraduate systems.

\section{Medicine III (General Surgery and all Surgical Specialties)}

The Committee of Medicine III considers that to have a concept 6 or 7 the program should show legitimate international participation and not just isolated integrations. Programs should be prepared to address emerging international challenges, especially in the area of knowledge production. This production should be evidenced through publication in high impact journals and distributed evenly among professors and students. High quality scientific production is the result of high quality projects, excellent professors, good students, research resources obtained from support agencies, and infrastructure from the institutions. This leads to better social integration of the graduates and the creation of new programs and courses.

\section{Education}

The area of Education assigns grades 6 and 7 to programs with a level of excellence compatible with the best international courses in the area, mainly in the USA and Europe. Not more than $10 \%$ of the programs evaluated have this profile. The main indicators of excellence are publication in indexed journals and in books - at the national and international level; participation in institutional research networks; exchange of professors and students; researchers with profiles compatible with foreign centers of excellence; the capability of nucleation of research activities; and social inclusion.

\section{Interdisciplinary}

The efforts of the Brazilian Postgraduate System towards internationalization have been gradually intensified in the Interdisciplinary Area, and these efforts have been evidenced by program grades within this group. Established programs in this area are equivalent to those in similar international interdisciplinary centers of excellence. The subjects of these programs include computational modeling and applied computation, studies of human aging, health surveillance, information technology in education, political science and technology, public policies, applied ecology, agribusiness, rural development and sustainable development. Regionally, the programs with the most outstanding degree of internationalization are concentrated in the South and Southeast of Brazil. There are also programs in association with foreign institutions in South America and Africa in the fields of agricultural economics and applied social sciences. The area has also registered a strong demand for sandwich doctoral and postdoctoral training in the USA and Europe. 


\section{Public Health}

The Public Health area brings together a relatively small scientific community worldwide accounting for about $1.9 \%$ of the scientific production registered in the SJR database. Production in Public Health corresponds to $6.4 \%$ of the production in Health which, in turn, accounts for $29.5 \%$ of all scientific production in the world. To access the production of the Public Health area recorded in SJR database it is necessary to add four different components: Epidemiology, Health Policy, Public Health, Environmental and Occupational Health (Medicine) and Health Social Sciences (Social Sciences). However, it is not possible to identify the part of Public Health published in diverse journals--medical, nursing and dentistry, plus other areas of health or biological sciences-which corresponds to almost $44 \%$ of the production of the programs. In the previous three years, international cooperation activities were intensified by the majority of the programs of the area.

\section{Sociology}

In the area of Sociology, grades 6 and 7 are reserved for programs classified as grade 5 in the first stage of realization of the triennial review that fulfill two required conditions: i) performance equivalent to international centers of excellence in the area; and ii) a highly differentiated level of performance in relation to the other programs of the area. These conditions are supported by a triplet condition of: a) scientific production with international participation, as evidenced by publication in media with higher evaluations, as per Qualis-Periodicals and Classification of Books; $b$ ) consolidation and national leadership of the program as a trainer of human resources for research and the postgraduate system; c) regional and national inclusion and impact; integration with other programs in the development of research and the postgraduate system; and visibility and/or transparency in operation.

\section{Nursing}

Internationalization in the Nursing area can be defined on two levels: international inclusion and actions aimed at internationalization of the programs. The dimension of international inclusion is mainly the result of the quality of the scientific production of permanent professors and students or graduates of the programs. This production is quantified by publication in journals in the field of global nursing. These journals must have impact factors (indexed in Wos/JCR and Scopus/Scimago), as well as international peer recognition, as evidenced by citations of articles produced by professors and students of the programs.

In addition to publications, international qualification can be measured by the presence of permanent professors as reviewers and editors on international journals; organization of (or participation by invitation in) international and domestic scientific events in Brazil; membership on boards and committees of scientific societies; raising of international funding from international agencies; participation in joint projects; participation in qualification boards and evaluation committees abroad; supervision of postgraduate students in other countries; and co-supervision of postgraduate theses, among others.

The actions aimed at internationalization can be identified in the mobility of professors and students in scientific activities, characterized both by going abroad as a visiting professor, a lecturer of disciplines and courses, by conducting postdoctoral courses, or doctoral sandwich courses, and other training and technical visits. It is also characterized by the receipt of foreign visitors (postdoctoral trainees and students to integrate the programs), and exchanges or reciprocal agreements between professors of the program and important foreign institutions in the field, among others. These actions are also reflected in a more global use of scientific English, a focus of the programs of the nursing area.

In Table 1 below, various items related to the main indicators of internationalization are presented, facilitating comparison. A similar relationship between these indicators was previously made by Lo Bianco, Almeida, Koller and Paiva (2010). The seven areas from above are represented. Information from the psychology area is also included.

It should be noted that Table 1 does not include all items relevant to the program. In some cases, these items constitute statements about why the program is highlighted in the area or, in other cases, the criteria relevant to the overall evaluation of the program but not specific to internationalization.

One such item is the grade 6 and 7 requirement that the program present "leadership at a national level" or is "prominent among the programs of the area." This requirement to confirm the programs are in higher positions within a hierarchy of quality is almost redundant. Another item requires that activities be evenly distributed among the professors, especially production; sometimes with the reservation that this balance must be especially evidenced among the most qualified professors. This was not considered an indicator of internationalization, unless balance of international production among the professors was required, as in some areas of the so-called "hard sciences." Only the demanding criterion of Medicine III that specifies that articles in high impact journals be well distributed among professors and students was maintained in Table 1. References to social integration also appear in all the areas and are not listed in Table 1, since they are one of the overall goals of the postgraduate system without exclusive association with internationalization.

Two operational aspects are also omitted from the set of items recorded in Table 1. One is the indication (common to all areas) that to achieve grades 6 or 7 , the program should be evaluated as "Very Good" in all items of the evaluation form (Proposal of the Program; Teaching Body; 
Menandro, P. R. M., Linhares, M. B. M., Bastos, A., \& Dell'Aglio, D. D. (2015). The Brazilian Psychology Postgraduate System and the Internationalization Process: Critical Aspects, Evaluation Indicators and Challenges for Consolidation.

Theses and Dissertations; Intellectual Production, Social Integration). The other aspect refers to the differentiation between programs 6 and 7, which are very specific for each area, involving internal comparisons.

Table 1

Comparison of Internationalization Indicators Among Different Areas of Knowledge

\begin{tabular}{|c|c|c|c|c|c|c|c|c|}
\hline CAPES Internationalization Indicators & Areas & knowl & & & & & & \\
\hline & Psy & Me 2 & Me 3 & Edu & ID & $\mathrm{CH}$ & Soc & Nur \\
\hline Int Art A1, A2 or B1 & $\mathrm{X}$ & & & & & & $\mathrm{X}$ & $\mathrm{X}$ \\
\hline Int Art A1 and A2 & & $\mathrm{X}$ & $\mathrm{X}$ & $\mathrm{X}$ & & $\mathrm{X}$ & & $\mathrm{X}$ \\
\hline Publ with foreign pship & $\mathrm{X}$ & & $\mathrm{X}$ & $\mathrm{X}$ & $\mathrm{X}$ & $\mathrm{X}$ & $\mathrm{X}$ & $\mathrm{X}$ \\
\hline Art Int by Student & $\mathrm{X}$ & & & & & & & $\mathrm{X}$ \\
\hline Books e Chpt abroad & $\mathrm{X}$ & & & & & & & \\
\hline Books L4 & & & & $\mathrm{X}$ & & & & \\
\hline Books L4 and L3 & & & & & & & $\mathrm{X}$ & \\
\hline Int Prod Impact - Cit Index & $\mathrm{X}$ & $\mathrm{X}$ & $\mathrm{X}$ & & & & & $\mathrm{X}$ \\
\hline Int Tech Prod Impact & $\mathrm{X}$ & & & & & & & \\
\hline Int or National Award & $\mathrm{X}$ & $\mathrm{X}$ & & & $\mathrm{X}$ & $\mathrm{X}$ & & $\mathrm{X}$ \\
\hline EdtBrd Foreign Jor & $\mathrm{X}$ & $\mathrm{X}$ & & & $\mathrm{X}$ & $\mathrm{X}$ & $\mathrm{X}$ & $\mathrm{X}$ \\
\hline Quali Board Coadv abroad & $\mathrm{X}$ & $\mathrm{X}$ & & & $\mathrm{X}$ & & & $\mathrm{X}$ \\
\hline Adv/Supv foreigner & $\mathrm{X}$ & $\mathrm{X}$ & $\mathrm{X}$ & & & & $\mathrm{X}$ & $\mathrm{X}$ \\
\hline Prof / Stud post doc Abr & $\mathrm{X}$ & $\mathrm{X}$ & $\mathrm{X}$ & & $\mathrm{X}$ & & $\mathrm{X}$ & $\mathrm{X}$ \\
\hline Doctoral Stud Training Abr & $\mathrm{X}$ & $\mathrm{X}$ & $\mathrm{X}$ & & $\mathrm{X}$ & & $\mathrm{X}$ & $\mathrm{X}$ \\
\hline Int Nat Society Board & $\mathrm{X}$ & $\mathrm{X}$ & & & $\mathrm{X}$ & $\mathrm{X}$ & $\mathrm{X}$ & $\mathrm{X}$ \\
\hline Int Financing Agency & $\mathrm{X}$ & $\mathrm{X}$ & $\mathrm{X}$ & & $\mathrm{X}$ & $\mathrm{X}$ & $\mathrm{X}$ & $\mathrm{X}$ \\
\hline Partic Int qualif event & $\mathrm{X}$ & $\mathrm{X}$ & & & $\mathrm{X}$ & $\mathrm{X}$ & $\mathrm{X}$ & $\mathrm{X}$ \\
\hline Proj with foreigner & $\mathrm{X}$ & $\mathrm{X}$ & & $\mathrm{X}$ & $\mathrm{X}$ & $\mathrm{X}$ & $\mathrm{X}$ & $\mathrm{X}$ \\
\hline Foreign Visit/invitation & $\mathrm{X}$ & $\mathrm{X}$ & $\mathrm{X}$ & & $\mathrm{X}$ & & & $\mathrm{X}$ \\
\hline Organization of Int Event & $\mathrm{X}$ & $\mathrm{X}$ & & & & & $\mathrm{X}$ & $\mathrm{X}$ \\
\hline Teaching in coop other IES & $\mathrm{X}$ & & & $\mathrm{X}$ & $\mathrm{X}$ & & & $\mathrm{X}$ \\
\hline Advy Capes / new Prog & $\mathrm{X}$ & & & & $\mathrm{X}$ & & & $\mathrm{X}$ \\
\hline Graduate $\mathrm{Adv}$ in $\mathrm{PG}$ & $\mathrm{X}$ & $\mathrm{X}$ & & $\mathrm{X}$ & $\mathrm{X}$ & & $\mathrm{X}$ & $\mathrm{X}$ \\
\hline Graduate relevant publ pos & $\mathrm{X}$ & & & & $\mathrm{X}$ & & & $\mathrm{X}$ \\
\hline Graduate Nat/Sta prod schol & $X$ & & & & & & & \\
\hline Doct deg val co-supervision & & $\mathrm{X}$ & & & $\mathrm{X}$ & $\mathrm{X}$ & $\mathrm{X}$ & \\
\hline Perf equiv to Int Center & & $\mathrm{X}$ & $\mathrm{X}$ & $\mathrm{X}$ & $\mathrm{X}$ & $\mathrm{X}$ & $\mathrm{X}$ & \\
\hline Mobility of Doct/Stud abr & & $\mathrm{X}$ & & & $\mathrm{X}$ & $\mathrm{X}$ & $\mathrm{X}$ & \\
\hline Int English discipline & & $\mathrm{X}$ & & & & & & \\
\hline$\%$ prod schol $>$ than area & & $\mathrm{X}$ & & & & & & \\
\hline Significant H-Ind- doc & & $\mathrm{X}$ & & & & & & $\mathrm{X}$ \\
\hline Art A good distrib Prof & & & $\mathrm{X}$ & & & & & \\
\hline Prof Abr IM/ID Int & & & & $\mathrm{X}$ & $\mathrm{X}$ & $\mathrm{X}$ & $\mathrm{X}$ & $\mathrm{X}$ \\
\hline Contrib improve Basic Ed & & & & $\mathrm{X}$ & & & & \\
\hline Publ for language jor & & & & & $\mathrm{X}$ & & & \\
\hline
\end{tabular}

Note. Psy, Psychology; Me 2, Medicine 2; Me 3, Medicine 3; Edu, Education; ID, Interdisciplinary; CH, Public Health; Soc, Sociology; Nur, Nursing. Abbreviations: Art, article; Int, international); Publ, publication); Pship, partnership; Chpt, chapter; Prod, production; Cit, citation; Tech, technical; EdtBrd, editorial board; Jor, journal; Abr, abroad; Adv, advisor; Coadv, co-advisor; Supv, supervisor; Prof, professor; Qualif, qualification; Stud, student; Partic, participation; Proj, project; Visit, visitor; Advy, advisory; Prog, program; Publ, public; Coop, cooperation; Prod, productivity; Schol, scholarship; Nat, national; Sta, state; Doct, Doctorate; Deg Val, degree validation; Perf, performance; Equiv, equivalent; H-Ind, H-index; Distrib, distribution; IM, interinstitutional master's; ID, interinstitutional doctorate; Pos, position; Contrib, contribution; Ed, education; For, foreigner. 
The considerations of the areas that were transcribed, as well as those that fulfilled the criteria in Table 1, show that the requirements for internationalization present many common elements when different actions are mentioned. These elements are both in the sphere of qualification and in the production of knowledge, i.e., research. Although the parameterization of each area is not identical (this point is beyond the scope of this text), these differences do not change the fact that general principles seem to be widely shared.

Within the international context, one can infer that the goals for achieving excellence and recognition among the Brazilian postgraduate programs are genotypically involved. Different actions that directly depend on professors and students (international publication, mobility of Brazilian and foreign professors and students, doctoral training, academic visits, joint projects) or that rely on academic institutions (partnerships, co-supervision, degree validation, acceptance of theses and dissertations in other languages) or even depend on research promotion institutions (agreements between Brazil and other participating countries, international research grants with the participation of Brazilian researchers) are phenotypically involved.

In addition to international inclusion, programs must present, as already noted, consolidated leadership in research and in the formation of talents and leaders at the national and international level, to earn a CAPES 6 and 7. The comparative aspect of the evaluation, within each area, is at the heart of the process. Comparability between areas is more difficult to ensure, but is also sought as part of the process. The programs analyzed may vary in emphasis, in detail or in the amplitude of their intellectual production and qualification activities aimed at internationalization; however, the essence seems to be the same. It should be noted that the initiatives of professors and students support the actions of internationalization through mobility and publications.

\section{Final Considerations}

The definitions of policies and strategies by academic institutions and research support agencies are still modest regarding the effective process of internationalization, even considering the specific variations with which the process manifests itself within the different areas. It should be highlighted that in the process of construction and consolidation of internationalization, major challenges are presented for Brazilian postgraduate programs.

The first and most obvious challenge in Brazil is language. For the aspiring researcher or student, who aims to publish for the global audience, their communication needs will exceed the limits of their native Portuguese. English is the current "academic-scientific language" for communication at the international level (as seen in international conferences). There is, however, a need to discuss the risk of the "Anglo-Saxonization" of the universities (Marrara, 2007), or of a process likened to neo-colonialism, not only for ideological reasons, but also because of commercial interests (Veiga, 2014). Furthermore, for a long time national programs have included language proficiency (almost always English) in their selection processes. In light of this, both teaching and student body must advance in resourcefulness in English-the language of international exchanges.

A second challenge is overcoming the bureaucratic barriers and obstruction of the Brazilian higher education institutions, which often hinder the establishment of agreements, degree validation, co-supervision, and mobility of professors. It is necessary to adjust the rules inherent in the university system to facilitate these processes, with the goals of establishing effective and productive partnerships for both sides. In this context, it must be stressed that in the foreign educational institutions there are requirements and fee payment rules, even for foreign students, which are negotiated between the institutions, on a case by case basis, when they could be normalized at the level of interaction between governments.

A third challenge relates to the lack of institutional support for the procedures necessary for internationalization, which overloads professors with all the initiatives required for the establishment of partnerships and the implementation of this process. In general, the processes of internationalization end up being associated with cases tied to an initiating professor, and thus do not reflect a wider goal (i.e., those of a consortium or set of professors).

A fourth challenge is obtaining updated information on the graduates of the postgraduate programs. This is important in order to ensure their involvement in research, with the postgraduate system, with important professional or management activities, and with their eventual leadership in the area. This is an aspect that requires improvement. It must be implemented jointly by the programs and by CAPES, possibly through a database of the postgraduate system that allows monitoring of graduates' professional development outside the sphere of academic life. Interestingly, a study on the evaluation of CAPES, published more than thirty years ago, also highlighted the importance of measuring the professional outcome of the graduates (Castro \& Soares, 1983).

A fifth challenge is to work towards a system by which state, national and international research support agencies would be able to participate in joint funding proposals with other countries, ensuring benefits for Brazilian science and technology. This point was a matter of concern in the set of the proposals contained in the text of Lo Bianco, Almeida, Koller and Paiva (2010).

A sixth challenge to be mentioned relates to the evaluation process itself. The term "international impact of the work published" is used to compare the production of the programs; but its definition still is less than clear. We are challenged to refine this measurement of international impact; but nonetheless it must be done. 
Menandro, P. R. M., Linhares, M. B. M., Bastos, A., \& Dell'Aglio, D. D. (2015). The Brazilian Psychology Postgraduate System and the Internationalization Process: Critical Aspects, Evaluation Indicators and Challenges for Consolidation.

Mechanisms sponsored by CAPES, such as the Qualis Periodicals and Classification of Books have been important to the evaluation of the programs; and as seen in Table 1, all the areas make mention of them. These mechanisms, however, do not address the challenge of measuring international impact. The impact factor available for periodicals of various areas, based on citations, was more relevant in the past than it is now. However, an effort to increase the indexing of Brazilian psychology journals in international databases is still justified, as the number of these journals is still limited (Packer, 2011). Indexing would facilitate access to the articles, and thereby increase their impact by broadening the base from which citations are taken.

The H-index methodology occupies part of this ground, perhaps partly due to the facility that computerized search programs provide in the academic context, and partly because it can be applied to both journals and researchers. In the eight areas that were examined for the production of this text, only Medicine II made explicit mention of the H-index methodology, which also considers citations relativized by the production volume. However, it is debatable whether the H-index methodology simplifies the process of measuring the international impact of certain scientific production.

Finally, it is important to mention the problem of imposing limits on the number of programs in each area that can achieve grades 6 and 7. This imposition is not clearly explained, however, plays a recognizable role in recent evaluations of the postgraduate system. In Table 1 , it is evident that one of the areas examined, Education, works with $10 \%$ of the programs, fulfilling the function of a self-imposed barrier (perhaps to avoid sanctions). The goal of internationalization requires the evaluation procedure to accept, in the various areas, any number of programs that meet the requirements to earn the higher grades of 6 or 7 .

\section{References}

Castro, C.M., \& Soares, G.A.D. (1983). Avaliando as avaliações da Capes [Evaluating CAPES ratings]. Revista de Administração de Empresas, 23(3), 63-73. Retrieved from http://dx.doi.org/10.1590/S0034- 75901983000300007.

Lo Bianco, A.C. (2009). Da globalização inevitável à internacionalização desejável [From inevitable globalization to desirable internationalization]. Revista Latinoamericana de Psicopatologia Fundamental, 12(3), 445-453. Retrieved from http://dx.doi.org/10.1590/S1415-47142009000300002.

Lo Bianco, A. C., Almeida, S. S., Koller, S. H., \& Paiva, V. (2010). A internacionalização dos programas de pós- graduação em psicologia: Perfil e metas de qualificação [Internationalization of postgraduate programs in psychology: Profile and qualification goals]. Psicologia: Reflexão e Crítica, 23(suppl. 1), 1-10. Retrieved from http://dx.doi. org/10.1590/ S0102-79722010000400002.

Marrara, T. (2007). Internacionalização da pós-graduação: Objetivos, forma e avaliação [Internationalization of postgraduate studies: Goals, structure and evaluation]. Revista Brasileira de Pós-Graduação, 4(8), 245-262.

Menandro, P.R.M., Yamamoto, O.H., Tourinho, E.Z., \& Bastos, A.V.B. (2011). Livros à mão cheia: O livro como veículo de produção acadêmica [Books as means of scientific publishing]. Psicologia USP, 22(2), 367-386. Retrieved from http://dx.doi.org/10.1590/S0103-65642011000200005.

Packer, A.L. (2011). Os periódicos brasileiros e a comunicação da pesquisa nacional [Brazilian periodicals and communication of the national research]. Revista USP, 89, 26-61. Retrieved from http://rusp.scielo.br/pdf/rusp/n89/04.pdf.

Veiga, F.H. (2014). Internacionalização da investigação e do ensino em Psicologia e Educação: Demandas Portugal-Brasil [Internationalization of teaching and research in psychology and education: Portugal-Brazil demands]. Estudos de Psicologia, 31(2), 149-158. Retrieved from http://dx.doi. org/10.1590/0103-166X2014000200001
Received: February 26, 2015 Reviewed: September 29, 2015 Accepted: May 25, 2015 